\title{
Artelogie
}

Recherche sur les arts, le patrimoine et la littérature de l'Amérique latine

5 | 2013

Femmes créatrices en Amérique latine : le défi de synthétiser sans singulariser

\section{Adriana Varejão : Cutting through layers of Brazilian History}

Adriana Varejão : Cutting through layers of Brazilian History

\section{Alice Heeren}

\section{OpenEdition}

\section{Journals}

Electronic version

URL: https://journals.openedition.org/artelogie/5796

DOI: 10.4000 /artelogie.5796

ISSN: 2115-6395

Publisher

Association ESCAL

\section{Electronic reference}

Alice Heeren, "Adriana Varejão : Cutting through layers of Brazilian History", Artelogie [Online], 5 | 2013, Online since 16 October 2013, connection on 20 December 2021. URL: http://journals.openedition.org/ artelogie/5796 ; DOI: https://doi.org/10.4000/artelogie.5796

This text was automatically generated on 20 December 2021.

Association ESCAL 


\title{
Adriana Varejão : Cutting through layers of Brazilian History
}

Adriana Varejão : Cutting through layers of Brazilian History

\author{
Alice Heeren
}

1 In his discussion of the Baroque tradition, Gilles Deleuze argues: "the baroque refers not to an essence but rather to an operative function, to a trait. It endlessly produces folds" (DELEUZE, 1992: 3). In a similar way, by appropriating disparate references in her work, contemporary Brazilian artist Adriana Varejão endlessly folds the past upon the present, wrinkling the apparently smooth surface of grand narratives.

2 The Entrance Figure series, which will be my focus here, is made up of three paintings created by Varejão between 1997 and 2005. In these 5,20 $\mathrm{m}^{2}$ canvases, the artist references the modern notion of Antropofagia, ${ }^{1}$ Portuguese azulejos tradition, and imagery appropriated from Theodore De Bry's Grand et Petit Voyages. In order to untangle the web of references layered in the Entrance Figure series and give insight into Varejão's oeuvre, I will explore the three main themes: the aesthetic of the Baroque, cannibalism, and the female body, exposing their textured structure.

3 Particularly, I am interested in how the female body becomes the surface upon which mythology is layered and identity is configured-and questioned-in these paintings. Borrowing from the iconography of De Bry, which in itself is already a palimpsest of historical references, Varejão conflates innumerable sources, transporting them onto the skin of the female protagonists; this subversion of their canonical use calls attention to the discontinuities within them. The artist demonstrates the fractioned and collaged and violent configuration of historical narratives raising awareness about the legacy of colonization in the country.

4 Issues of race and gender as well as the way identity discourses are underlining questions in Varejão's oeuvre. The artist pulls back the layers that have made up the notion of Brazilianess, highlighting how the construction of a modern national identity is a process that brings together disparate pasts and visions of the future. By highlighting the obsession with the question of identity in the New World and how it 
has been central to the intellectual life of nations like Brazil until today, ${ }^{2}$ Varejão engages with a long intellectual history marked by the works of Gilberto Freyre, Oswald de Andrade, Sérgio Buarque de Hollanda, Roberto DaMatta, Darcy Ribeiro, Roberto Schwarz, among others. ${ }^{3}$ It is the mechanisms of historicizing the past and creating a shared identity that Varejão puts in check by unveiling the repression of multiplicity inherent to this process.

5 Nation building, as Benedict Anderson notes, is based on the complex creation of an idea of temporal simultaneity. A shared history is achieved through the apparent seamless juncture between past and present (ANDERSON, 2006). It is this smooth teleological narrative of Brazil's past that Varejão is destabilizing in her work. I see the Entrance Figure series as an enactment, at the level of form, of this identity formation constructed through the absorption of disparate references. Thus, I will examine how these works, individually as well as in their grouping, visually perform the process of welding past and present together. Furthermore, I argue that through subtle disruptions to the homogeneity of these grand narratives, Varejão unearths the intrinsic symbolic violence in them, revealing underlining seams. Ultimately, I am positing that by manipulating the iconography and the materiality of painting, Varejão mimics the mechanism of formation of national identities.

Clearly, the Entrance Figure series and Varejão's work as a whole have several points of entry and are diverse systems of meaning, however I want to examine it through the lens proposed by Berber Bevernage when he argues that instead of being a neutral analytical frame, history can be performative... historical language [can] not only [be] used to describe reality but it can also produce substantial socio-political effects... bringing into being the state it describes (BEVERNAGE, 2012: 15). I posit in this article that pictorial language can do the same. By enacting the process of identity construction through painting while subverting the iconography that has traditionally been its building blocks, Varejão's works are performative pieces that highlight the legacy of colonization and conceptualize the notion of Brazilianess in the postcolonial era.

7 Most of the travelers' chronicles produced during the exploration voyages of the sixteenth century were compiled in Theodore De Bry's Thesaurus de Viagens ou Collectionnes Peregrinatorum in Indiam Occidentalem et Indian Orientalem, better known as Petit et Grand Voyages. It is from this work that Varejão appropriates the iconography for the Entrance Figure series. Made up of 13 sections, the Grand et Petit Voyages' first three books, Admiranda Narratio (1590), Brevis Narratio (1591) and Americae Tertia Pars (1592)based on the trips of the English to Virginia, Laudonnière to Florida, and Hans Staden and Jean de Léry to Brazil, respectively-are the most important for my analysis. ${ }^{4}$ Varejão was clearly conscious of how De Bry shifted the focus in his engravings from the male Europeans, protagonists in the traveller's chronicles, to the native female body.

The female body in Varejão's work becomes then the space of contention where the civilization/barbarism binary opposition-the ultimate justification for the violence of the colonial enterprise-is unveiled. While one could say that the first two layers of Varejão's Entrance Figure I are appropriations of baroque tiled panels that were used to decorate the entrances to Portuguese palaces, convents and gardens, this composition focuses on the body as support, as the tissue on which history is written. In order to dissect the layers of iconography laid onto this body the best starting point is the narrative at the backdrop of the Entrance Figure series and its focus on cannibalism. ${ }^{5}$ 


\section{Cannibalism and gendered bodies}

The association of the New World with cannibalism was ubiquitous in sixteenth century literature and imagery, and central to the creation of the myth of the Americas. ${ }^{6}$ Negotiating between the myths of the noble savage and the cannibal, these tropes have been re-appropriated during the different phases of decolonization in various countries of Latin America. For instance in Brazil, in the 1920s, with he work of Oswald de Andrade and the paintings of Tarsila de Amaral, cannibalism, that had been a staple of the work of Montaigne, Rousseau, and other intellectuals that defined the idea of the New World, was appropriated and inverted. In an impulse to grapple with the colonial past and construct a Brazilian identity, De Andrade's work became a central source. Ultimately, "Manifesto Antropofágo" (Anthropophagy Manifesto, 1928) proposed a new way of approaching European influences. De Andrade found in the cannibalism of the Tupy Indians- and in European references like Montaigne, Freud and Nietzsche-the analogy for the absorption of European modernism by Brazilian artists. ${ }^{7}$ Henceforth, the term antropofagia -and its implication of ritual cannibalism-has been central to the relationship between Brazilian and European art. ${ }^{8}$

10 Nevertheless, De Andrade appropriated only one facet of the myth of cannibalism. The cultural politics of cannibalism from classical antiquity to the twentieth century has always been marked by a dichotomy: ritual cannibalism on one side, and a macabre taste for human flesh on the other. ${ }^{9}$ In European imagery these two sides were symmetrical opposites that marked the division between the ideal of the noble savage and the barbarians.

In the first form of cannibalism, the ritual of antropofagia, the absorption of the enemies' energy and agency is a form of respect. De Andrade based his work on this: eating a being like you for the native was not hating him. On the contrary, the warrior ate those that looked to him superior. The other, owner of many supernatural gifts, would be absorbed bringing him closer to the shamans (DE ANDRADE and BOAVENTURA, 1990: 7). By ingesting the enemy's body, the native also absorbed his strength, intelligence and leadership. This ideal of ritual cannibalism, practiced by the noble savage in an idealized connectedness to nature, was in European imagery always opposed to the image of the native consuming humans for the sake of pleasure.

Interestingly, this dualism in the narratives of European travelers constantly reflected patterns of trading and military alliances in the New World. A discourse created to justify colonialism, the image of savage flesh-eating barbarians was transplanted onto the native tribes who challenged European hegemony, like the Tupinambá in Brazil, while the ritual antropofagistas (those that performed ritual of antropofagia) were those considered European allies in the colonies.

Moreover, this association was also a gendered one as the female natives were often depicted as blood thirsty and physically deformed by the years of consuming human flesh, while male cannibalism was more commonly associated with warrior practices. (CHICANGANA-BAYONA, 2009) As Chicangana-Bayona and Sawczuk have discussed in their article "Bruxas e índias filhas de Saturno," the female natives of the New World were associated with the European imagery of witches through the practice of cannibalism. These figures personified the fears of European society, the threats of perversion, vices and sins. ${ }^{10}$ It mirrored Europe's own misogyny, the discourse of 
female perversity exemplified in the story of the expulsion of men from the Garden of Eden, triggered by female weakness for sin: it was through Eve that evil entered the world. As early as Vespucci's letters, the female natives were said to lead men to the loss of their soul, influencing heavily the myths surrounding the American woman.

In order to interpret the manipulation of the image of the cannibal, Varejão conflates the idealized notions of ritual of antropofagia and the idea of the consumption of human flesh. The artist exposes how the cannibal, rather than a representation of the natives, was in fact a window into the anxieties of European society. The natives, and particularly the female native's bodies, were the surfaces upon which Europe transposed its racial and gender bias engendering superiority and justifying the genocide of the inhabitants of the New World.

\section{Gendered bodies: civilized vs barbarian}

The images appropriated by Varejão for the background of Entrance Figure I are influenced by the legacy of the Enlightenment discourse and the civilized/barbarian binary it consolidated. Originally engraved for De Bry's Americae Tertia Pars to depict stages of the ritual of antropofagia, such as dismemberment and evisceration of the body, preparation of the pyre and caldron, and cooking of body parts over the fire, (figs. 1 and 2) in Varejão, these images are subtly inverted. I will elaborate on this visual language in the later section, but it is important to note that calling attention to the female bodies through the composition, the artist obfuscates the men that were also part of De Bry's ensemble in order to question the association between European chronicles of cannibalism and the female body (fig. 3). 
Figures 1 and 2 - Theodore De Bry, Americae Tertia Pars, 1592

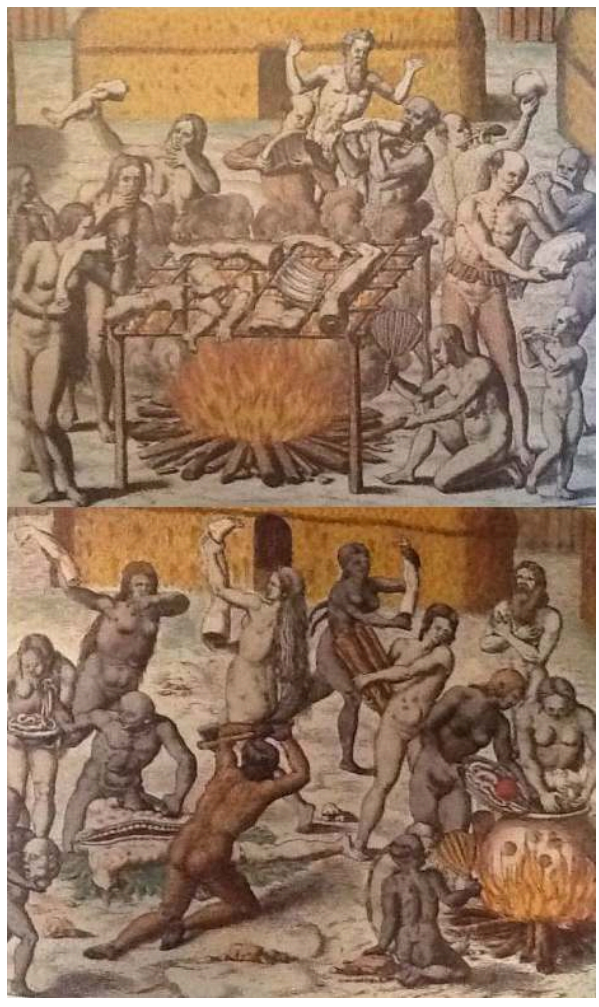

Image from DE BRY. Theodor. Americae pars I/XIII. Francoforti ad Moenvm, 1590-1634 Image in the public domain

Figure 3 - Adriana Varejão, Figuras de Convite (Entrance Figure I), 1997

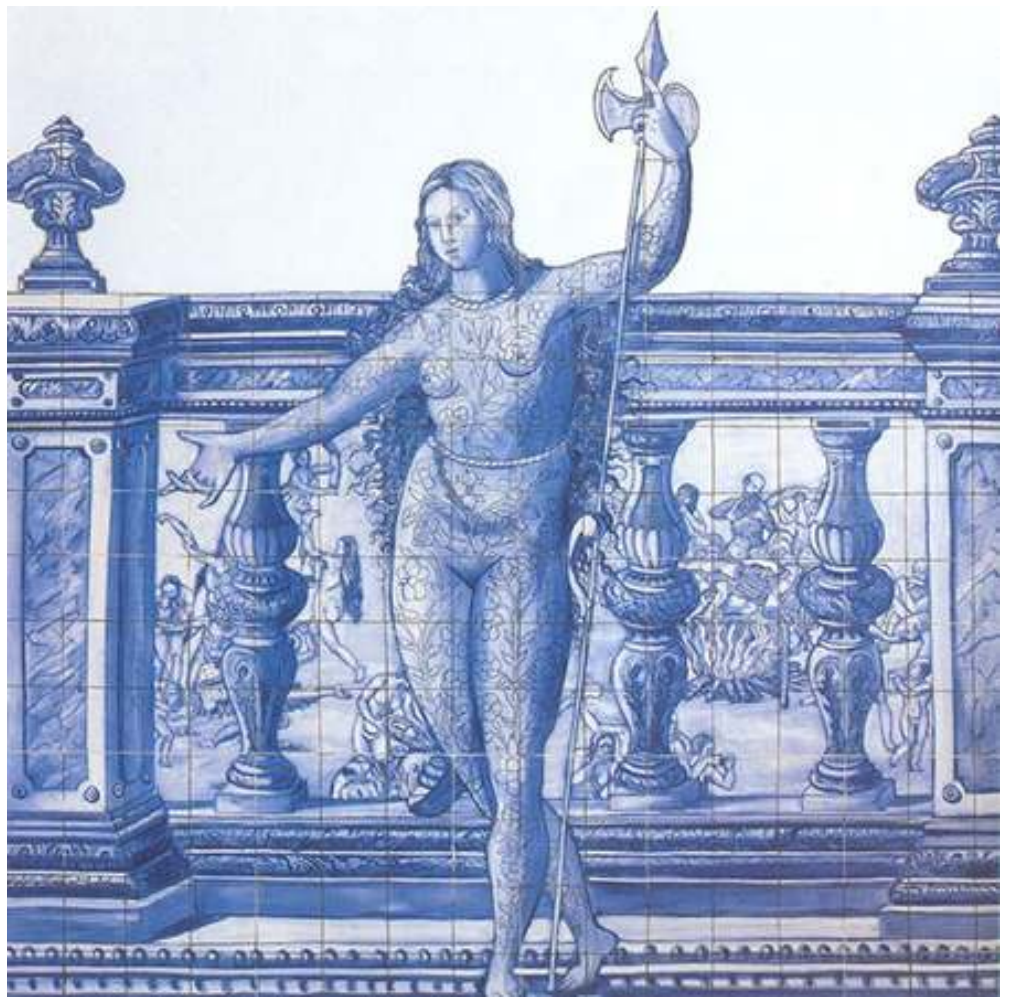



out the only adult male left in Varejão's collage: the figure of Hans Staden. In De Bry's original depiction of the story of Staden's capture by the Tupinambá, this figure is always presented with full beard, head of long hair and in actions that differentiate him from the short haired and well-shaved "barbarians." This mode of representing the natives was commonplace at the time of Grand et Petit Voyages. Most of the artists who created the images of the New World had never actually been to the colonies, or even when they had or were taking cues from primary testimonies, engravers like De Bry referenced images from the history of art: the classical past, the medieval period, and the revival in the sixteenth century. naked man, well proportioned, with short hair and entirely hairless body (CHICANGANA-BAYONA, 2006: 17). Female beauty, as discussed by Francisco Pacheco's El Arte de la Pintura (1649), was in turn attributed to the integrity of the members, proportion of the body, and color of the skin ("their pale whiteness"). Alberti adds to these ideals voluptuousness of the body and long hair. Clearly ancient Greek models and Renaissance iconography are the central references for the configuration of these ideals and both natives and Europeans shared those traits in De Bry's imagery.

Consequently, it is important to realize that the differences between the civilized and the barbarian were configured in early images of the New World not by physiognomy, but by the situation the bodies were inserted in, their tools and body markings. Interpreters of De Bry have gone further to argue that the criteria for differentiation in images from Grand et Petit Voyages were gestures that were thought to manifest the natives' external passions. ${ }^{11}$

Nevertheless, more than the moods of the soul, the movements and posture of the figures were meant to depict different levels of civilization. While the natives in De Bry's prints surround the pit where the body parts are being cooked, raise the severed limbs upwards as if in veneration, lick their fingers in the ecstasy of consumption of flesh. Hans Staden-the representative of European civilization in these images-is revolted and shocked by the cannibalistic practice of the Tupy. He shields himself from the ritual by raising his arms as in a prayer or crossing them over his chest, his face showing disgust in facing the cannibal practice of the natives (detail figs. 4 and 5). 
Figures 4, 5 and 6 -'Details Varejão's'Entrance Figure I (on right) and De Bry's, Americae Tertia Pars.

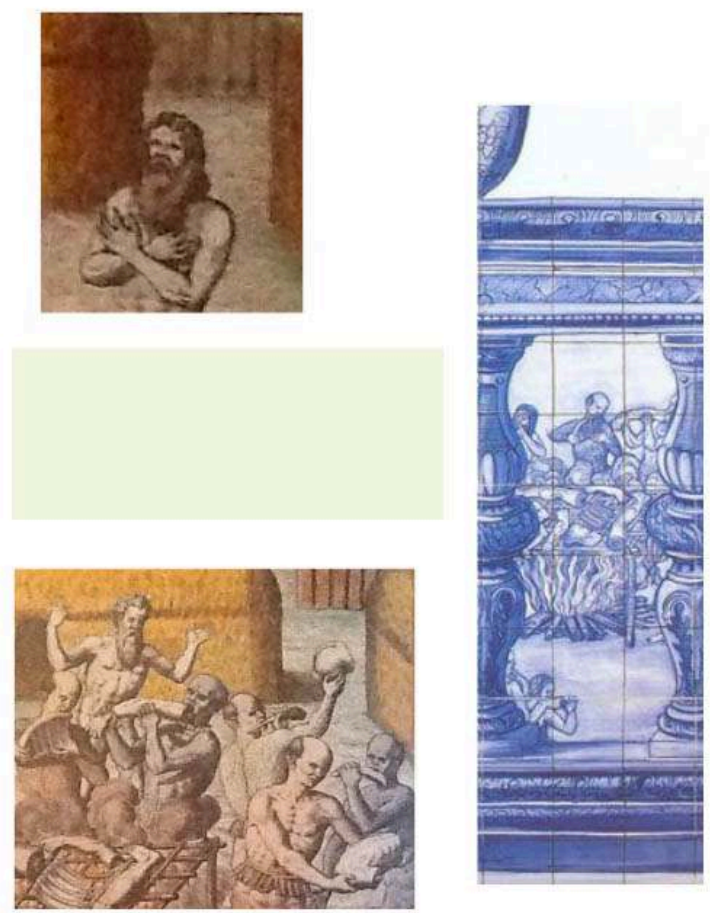

At first glance, it may seem that Varejão only passively appropriates these allegorical figures from De Bry. However, after a closer examination, it becomes clear that these citations are reconfigured in order to upset the master narrative of Western art history and the hierarchies perpetuated by them. Diverging from the original posture of Staden in De Bry's engravings, in Varejão's painting, the figure is eating human flesh in tandem with the natives. He holds a severed limb up to his mouth and displays the same expression of ecstasy as the natives surrounding him (detail fig 6.). The banister structure frames this action in the right side of Entrance Figure I. Varejão's commentary here is compelling in that it dismantles the civilized/barbarian dichotomy by subverting the iconographical mechanisms with which De Bry articulates European civilizational discourses. 
Figure 6 - Philippe Galle's America, 1581

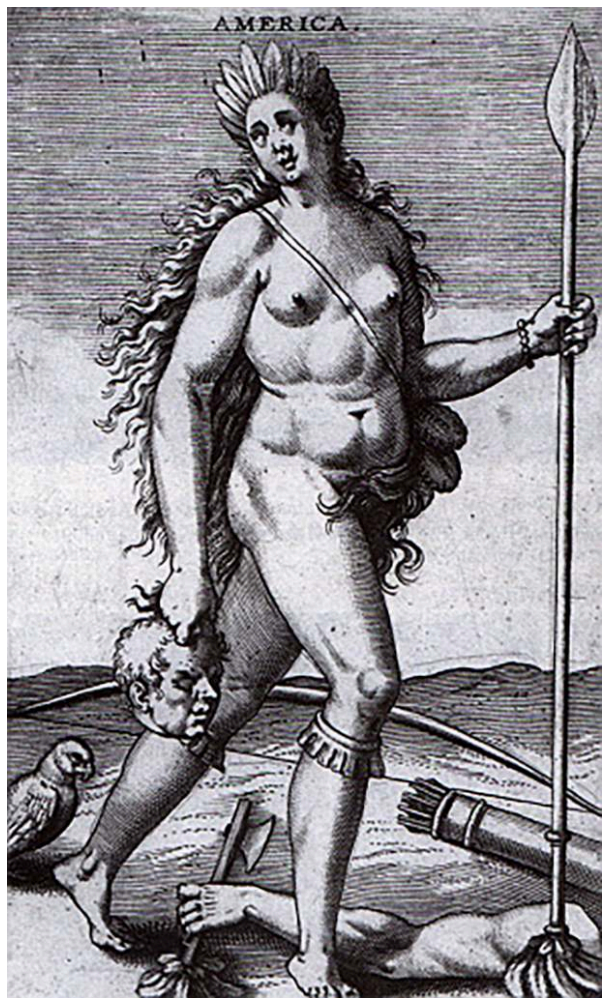

Image in the public domain

20 Varejão highlights how the binary opposition between Europeans and natives emphasized by De Bry, did not line up seamlessly, but in fact demanded the layering of several iconographical markers on the bodies - and in the actions - of the figures in the engravings.

\section{Christian iconographies}


Figure 7 - Typus Cosmographicus Universalis, 1532.
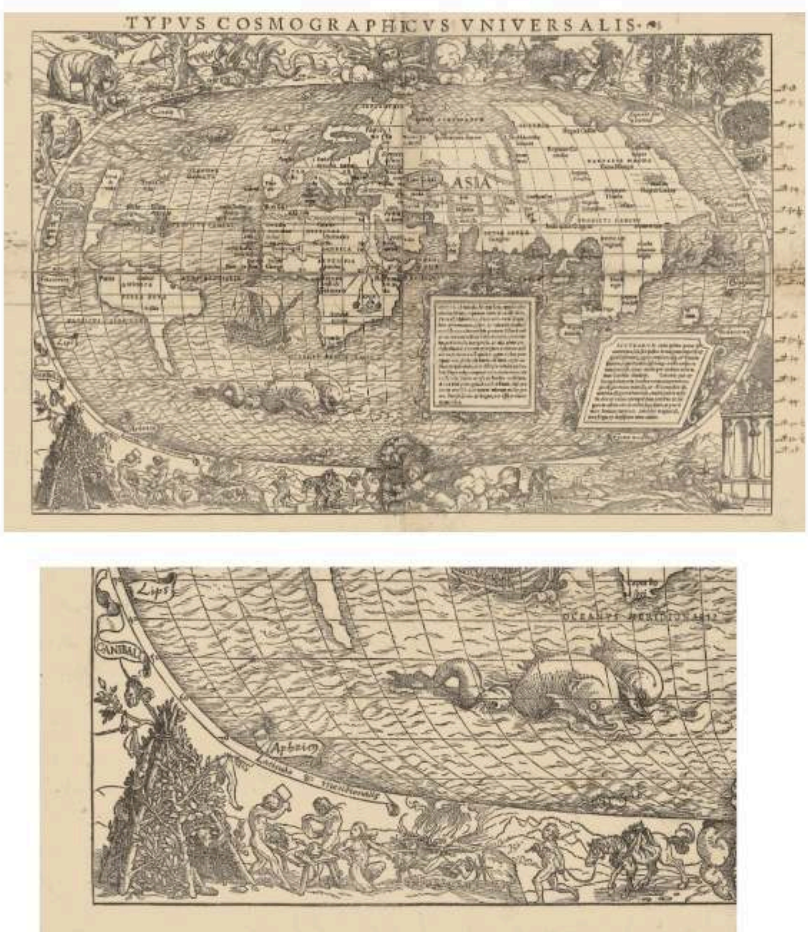

Image in the public domain

21 The body in parts is one of these key iconographical images. Following engravings like Phillippe Galle's America (fig. 7) and early maps of the region such as Typus Cosmographicus Universalis (1532) (fig. 8) and Diego Guttiérrez's 1562 Western Hemisphere map (fig.9), the body in parts, whether carried by the natives, hanging from trees or cooking on the pyre, became the central marker of barbarism. 
Figure 8 - Diego Gutierrez, Western Hemisphere (map, 1562.

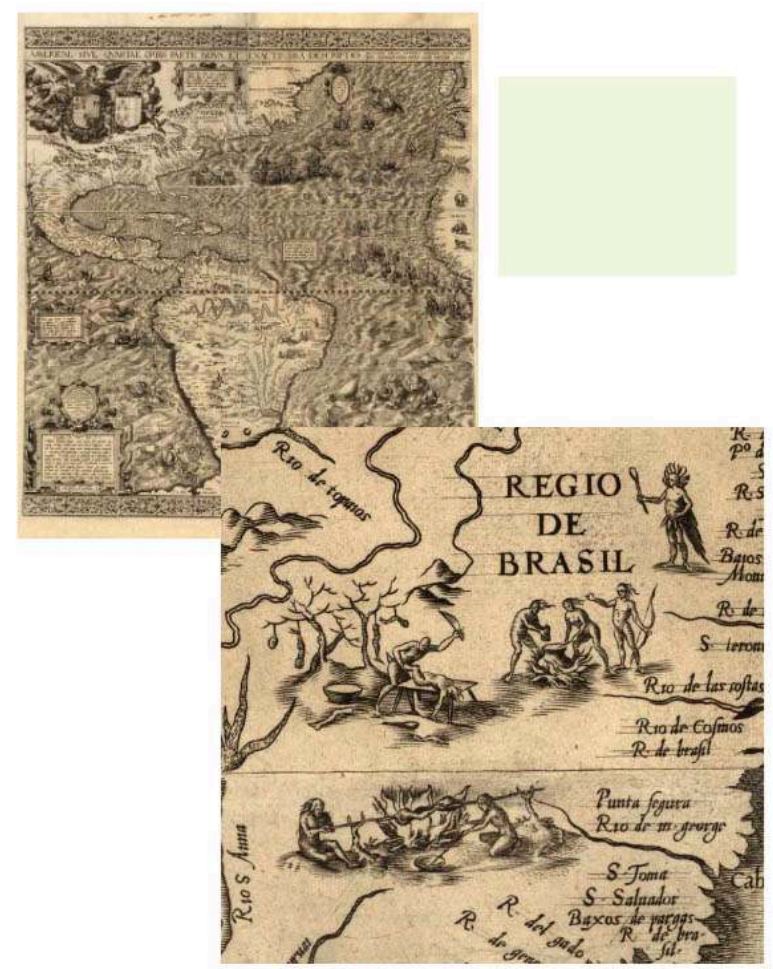

Image in the public domain

Figure 9 - Phillipe Galle and Martin de Vos, Judith, c. 1550

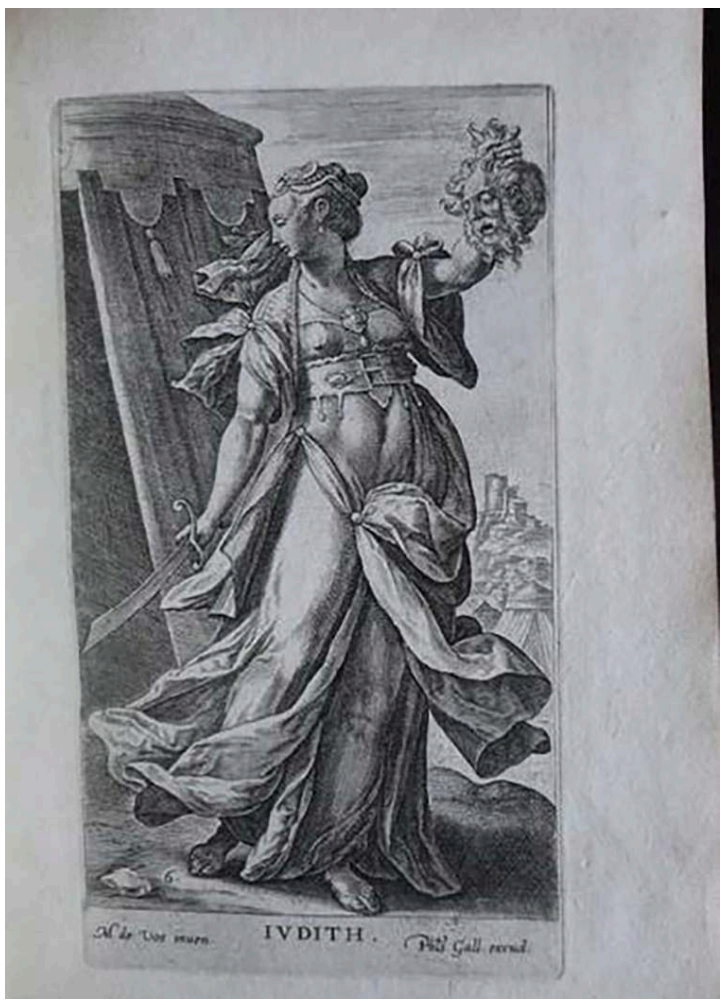

Image in the public domain 
The use of this element shows Varejão's deep knowledge of the historical sources appropriated by De Bry and calls attention to their Catholic overtones by recalling the resemblance of these figures with those of Salome and Judith (figs. 10 and 11). Again Varejão calls attention to the discontinuities in the civilized/barbarian binary. While the severed head, a staple of traditional representations of Salome are meant to symbolize the seductive, dangerous and malicious potential of women, the one depicted with Judith evokes nationalism and unwavering belief in God.

Figure 10 - Lucantonio degli Uberti, Monogrammist FF, Herodias [sic; Salome] with the Head of John the Baptist, 1580

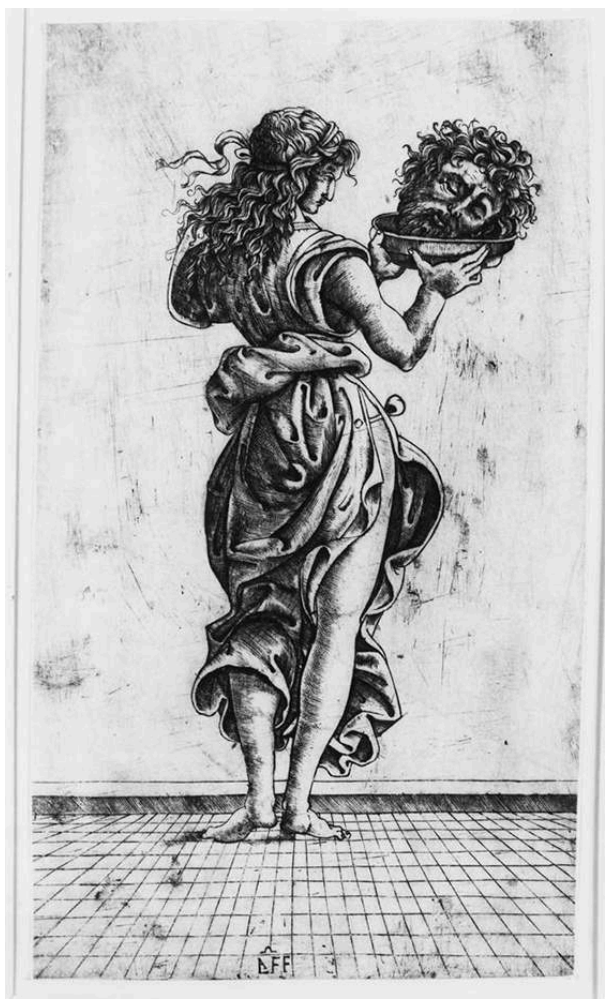

Image in the public domain 


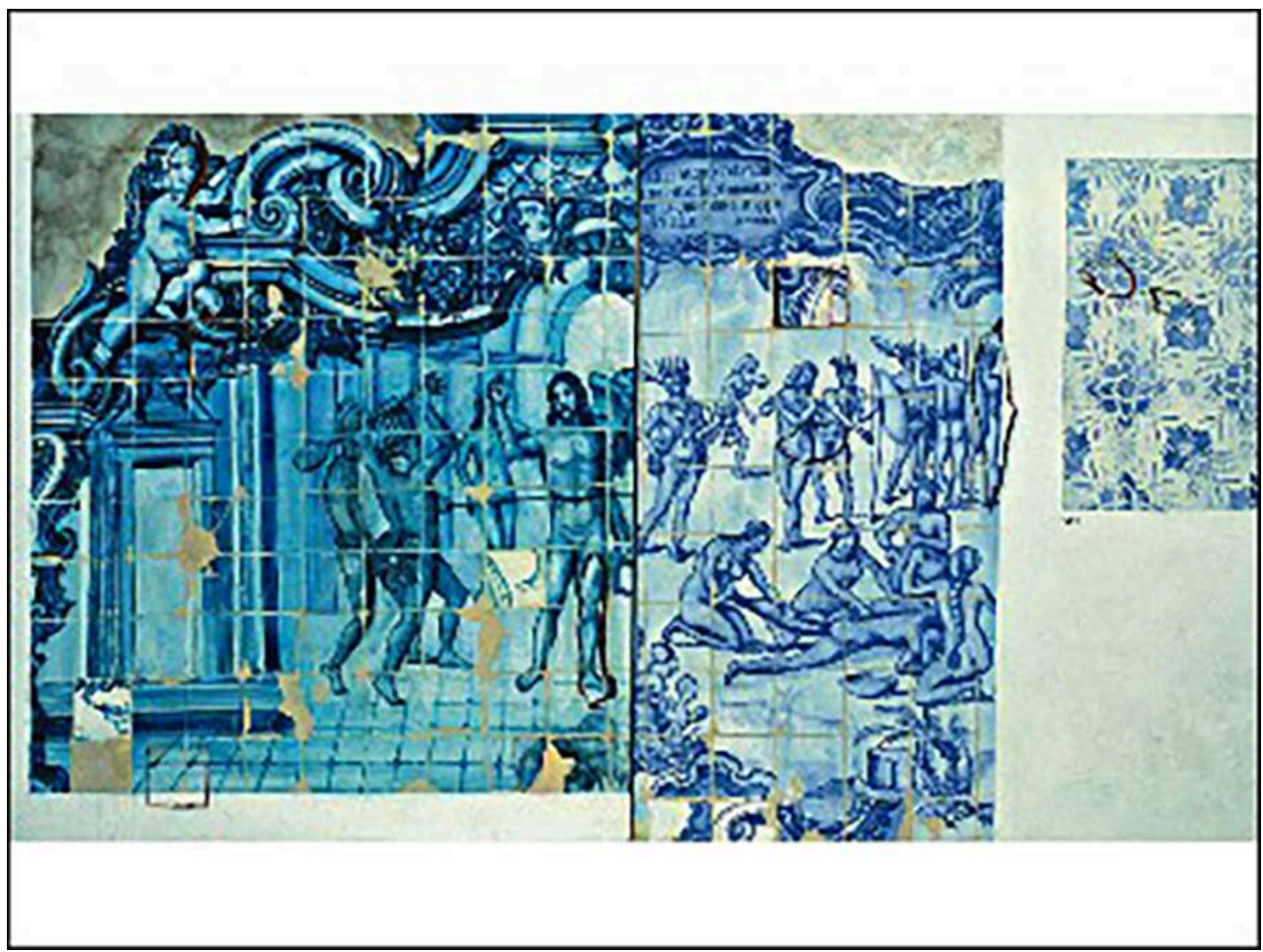

Varejão had already delved into these questions in Proposal for Catechesis (1993-1997) (fig. 12), where she conjoined the Christian miracle of transubstantiation with the practice of cannibalism, folding them onto one another by again appropriating the work of De Bry. Here Varejão uses the illusion of a collaged surface of ceramic tiles, book pages, and crumbling walls to combine the iconographies of cannibalism and of Catholic Eucharist. This connotation is most clearly evoked in the figure in the foreground to the left of the panel. This figure, about to be mow down, recalls the canonical depictions of Jesus Christ in European imagery. The same native man who is about to hit Christ is showed again in the background of the second panel where he is watching the women as they eviscerate and slice up the body of a Christ-like figure. While in the background of Entrance Figure I Varejão equates, in the figure of Hans Staden, civilization and barbarism, by implicating European civilization in the act of cannibalism, in Proposal for a Catechesis, the artist likens the Catholic ritual of Holy Communion to the pagan practice of cannibalism. The impact of the work is exacerbated because the religious civilizing mission was justified by the Catholic Church as one that aimed to eradicate pagan practices in the New World in order to civilize its inhabitants and make them more like the Europeans.

Figures 12 and 13 - Female holding leg in Varejão's Entrance Figure (left) and in De Bry's, Americae Tertia Pars (right). 

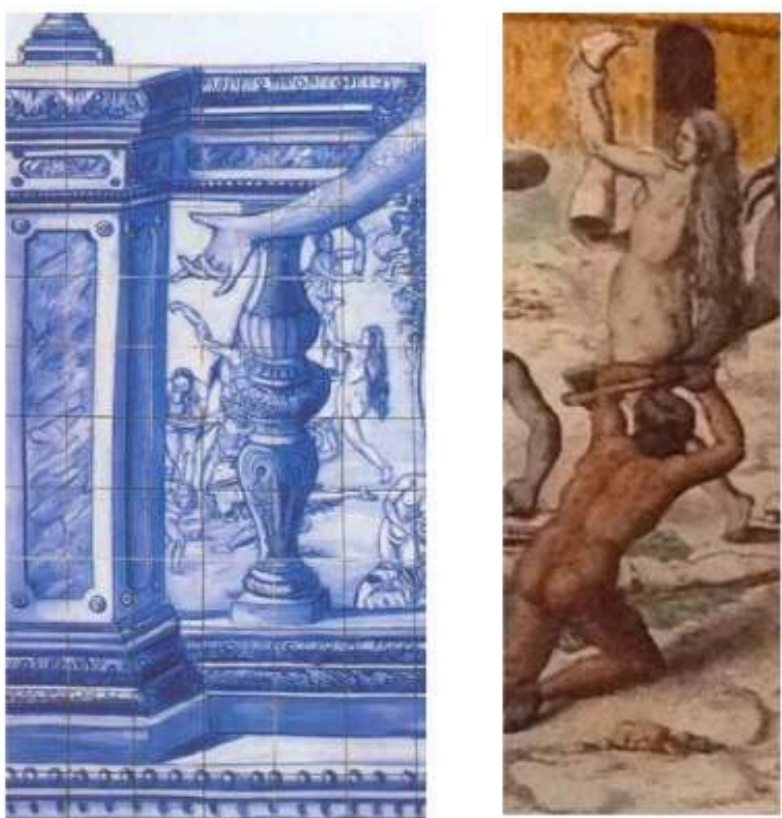

Image in the public domain

Varejão subverts this religious narrative by conflating the practices of the native "barbarians" and the "civilized" Europeans that De Bry worked so hard to separate in his engravings. The artist further signals to this connection in the cartouche painted on top of the right panel with an inscription from St. John's reports on the words of Christ: He that eateth my flesh, and drinketh my blood, abideth in me, and I in him. ${ }^{12}$ Thus, Varejão's Proposal for a Catechesis and the Entrance Figure are important critiques to the role of religious institutions in the physical and symbolic violence of colonization. The artist shows the natives eating the European missionaries, quite literally taking in the catechism they were force-fed. She denotes that eating the flesh of another-the act of barbarism par excellence in sixteenth century European literature-could be seen as part of European practices as much as it was asserted to be the center of native rituals. Furthermore, Varejão approximates the practices of cannibalism and of the Holy Communion to the point of causing discomfort of contemporary viewers, revealing how deep are the effects of the Enlightenment discourses of civilization in contemporary thought.

\section{European aesthetics and brazilian society}

Similarly, following the civilizing discourse of the Catholic Church, the use of baroque aesthetics - particularly in the form of the azulejo tradition -in Varejão's work, recalls the use of this material and its pictorial potential in sixteenth century Brazil as a form of ecumenical persuasion (NERI, 2001: 14). Varejão's interest in the azulejos, like her predilection for De Bry's engravings, is likely related to their character as dense material with several historical references. On one hand, the azulejos evoke the Moorish artisans who were central to the cultural life of the Iberian peninsula, and on another, 
the Eastern Song porcelain technique brought to Portugal in the Middle Ages and later adapted to the ornamental formulae of the Italian Renaissance. These blue and white ceramic pieces described by Count Anathasius Raczynski as part of Portugal's physiognomy were appropriated wildly in Brazil.

The Baroque's iconic standing was carried from Portugal to the colony and can be observed for instance when the modern garden designer Roberto Burle-Marx says in the 1930s that the Baroque and the Rococo are admirably adapted to the Brazilian landscape (...) The country is so Baroque that one has the impression that the style was born here (CASTEDO, 1964: 23). This naturalization of the Baroque movement as reverberating with the psychopathology of Brazilian society has been recuperated in different eras, and together with other myths of origins has helped consolidate the ideal of Terra Brasilis. ${ }^{13}$ By appropriating the tiles, but subverting their iconography, Varejão highlights the way the baroque aesthetic was used in the colonization of the Brazilian natives and how this history has been obscured in the discourse of recuperation of this material. ${ }^{14}$ Thus, Varejão "writes" her narratives in azulejos; she creates paintings that hyper realistically mimic tiled panels, the key artistic tools in the colonization of the natives' belief system.

In the Entrance Figure series in particular, Varejão also highlights how the gender and race bias permeating De Bry's images has been carried down from Europe to Brazilian identity. While the male body, markedly that of Hans Staden, is the civilized European man, the female body is where the flesh-eating barbarian meets the noble savage, the maternal and domestic muse meets the perverse, macabre and sensual witch. Native women evoke in images of the New World the ambiguous nature of the civilized/ barbarian dichotomy because they are presented simultaneously as the Virgin and Salome, the epitome of civilization and of barbarism.

The left part of Entrance Figure I's background further elaborates on this tension between gendered bodies. As I have pointed out, the role of women in the practice of cannibalism and their behavior as they dance around the man who cuts the prisoner's body has, been isolated in Varejão's painting by the use of the banister. Its columns hide the men who in De Bry share in the cannibal practice, while the women dancing around these men are framed by the structure. Varejão juxtaposes the domesticity of these scenes-the family dining ritual-with the act of cannibalism, by highlighting the children who stand at either side of the canvas. 


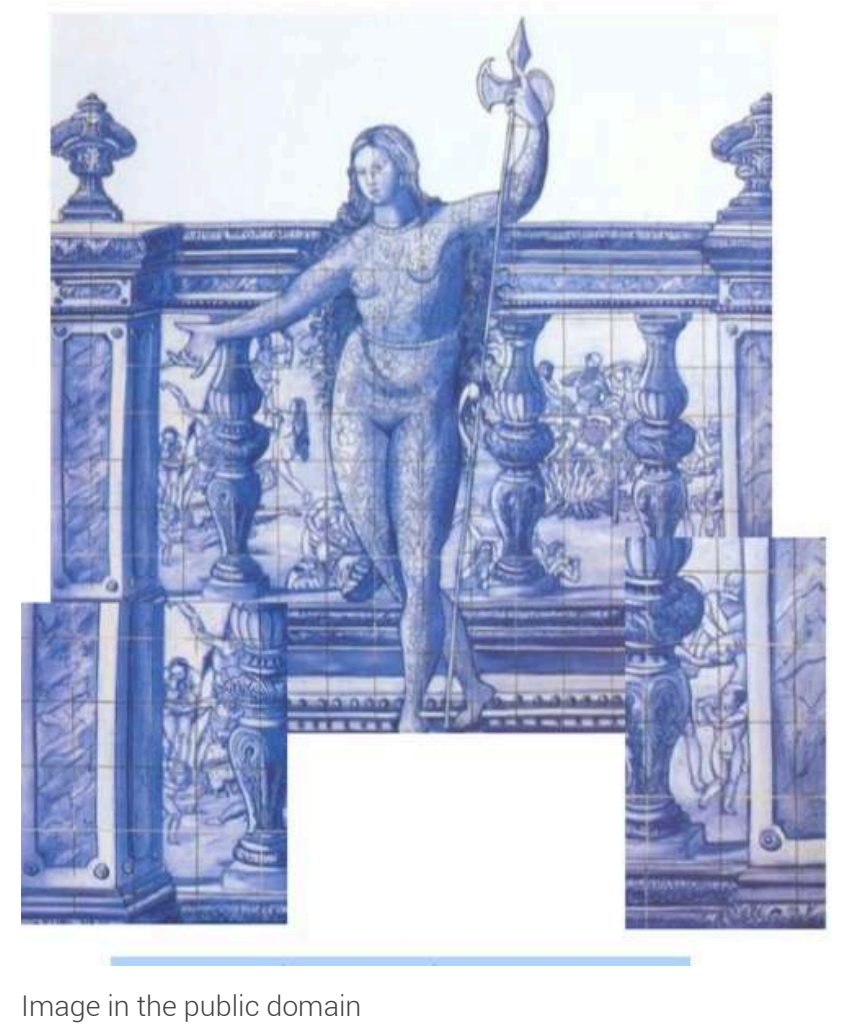

One of the women is particularly central to the composition (detail figs. 13 and 14); she is framed by the second section of the banister and is depicted with her back to the viewer. Her face is in profile as she looks up at the severed limb in her hands. Physically, the figure is based on the classical Greco-Roman models with her voluptuous body and long hair. The painting exposes the indistinguishable anatomical features of classical goddesses, witches, Eve, Salome, Judith and native women. Although the natives have different skin tones, their physiognomy is clearly based on Greek models. Even the women's poses and the two children who bookend the composition of the print Varejão appropriates, reveal the inspiration from Greek sculpture (detail figs. 15 and 16). The difference in skin tone contrasting with clearly European "white" physiognomy points to the European's inability to deal directly with the question of race. The conflation of the cannibal and the noble savage (in the classical references used as basis for the representation of the Indians) made it difficult to fit into European categories of racial evolution. ${ }^{15}$

Finally, it is in the protagonists of Varejão's paintings that the strategies of appropriation and subversion of traditional iconography are most clearly articulated (fig. 17). These figures were named entrance figures because they recall the servants that framed the path of kings and the aristocracy in earlier European ceremonies. In Varejão's paintings they invite the viewer into the world of cannibalism and native "barbarie." In particular, in Entrance Figure I, the figure is recognizable as the one found in the stairway of the Palácio da Mitra in Santo Antão do Tojal, Portugal, from circa 1730 (fig. 18). The most important difference is how Varejão substitutes the male servant pictured in this Portuguese tile panel with a figure of a female Pict taken from another engraving in De Bry's Grand et Petit Voyages (fig. 19). Varejão re-performs the 
switch De Bry articulates from the male civilized European to the female "barbarian" body.

Figure 17 - Detail Entrance Figure I - main figure

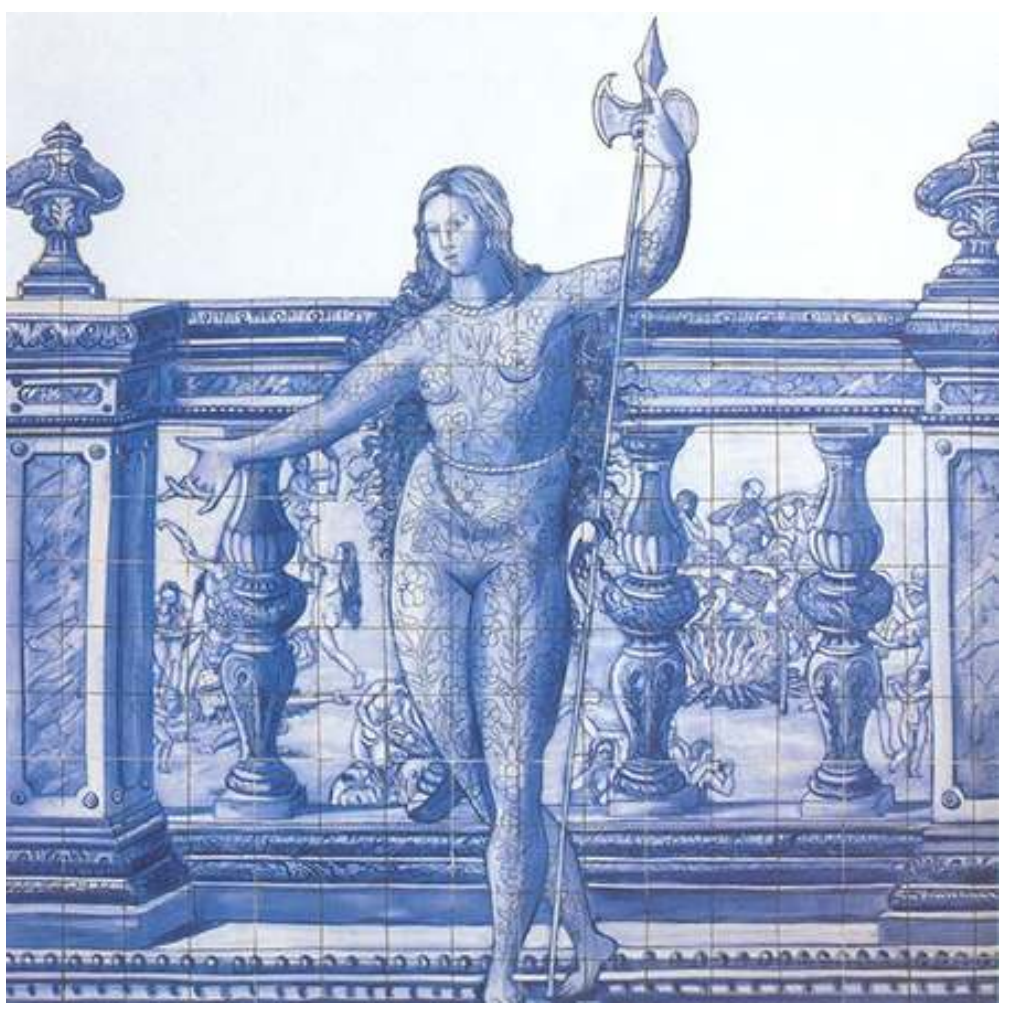

Figure 18 - Detail panel (circa 1730) from Palácio da Mitra in Santo do Tojal, Portugal

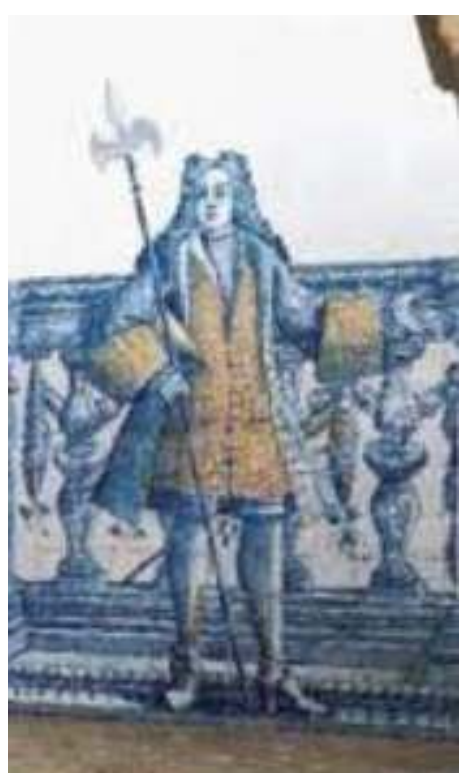


Figure 19 - Theodore De Bry's Pict (Image in the public domain)

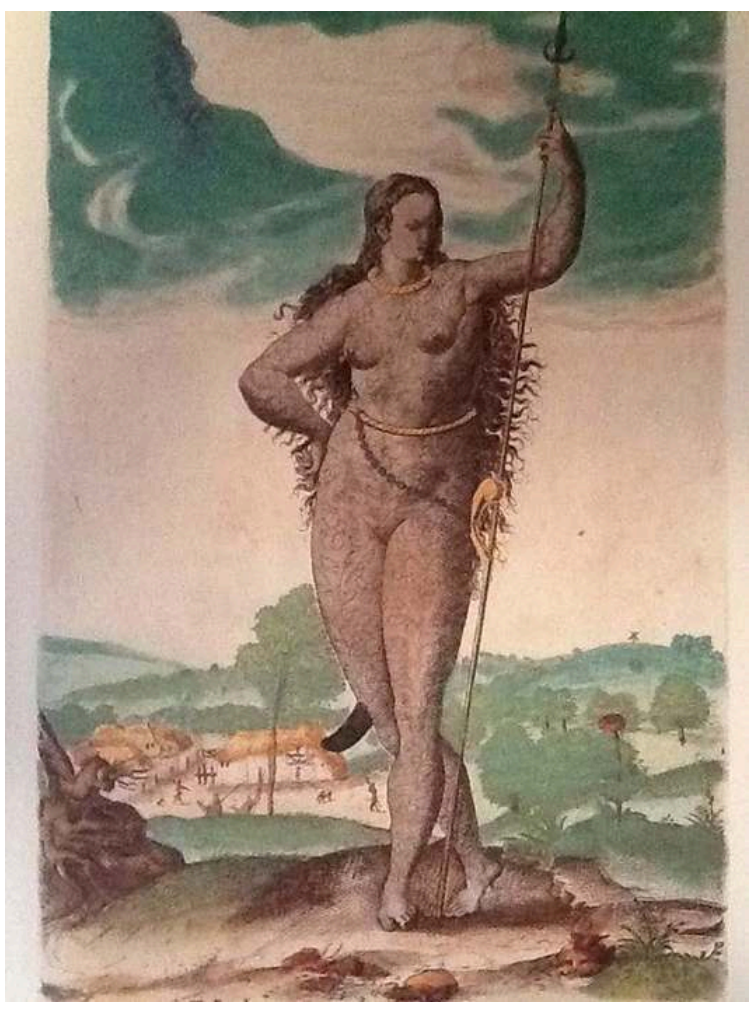

31 The images of the Pict Varejão appropriated from De Bry were, in turn, borrowed from John White's drawings (fig. 20). ${ }^{16}$ They were ancient inhabitants of England who received their names from the form of body art they practiced. These figures were important for European evolutionary narratives as they pointed to the possibility of evolution from cannibal primitives into civilized Europeans. The figures of Pict rendered by White - and later by De Bry - were characterized as the "barbarian" precursors of the European "civilized", an iconography marked by the dismembered heads the figures carry. 
Figure 20 - John White's A Woman 'Pict', 1585-93

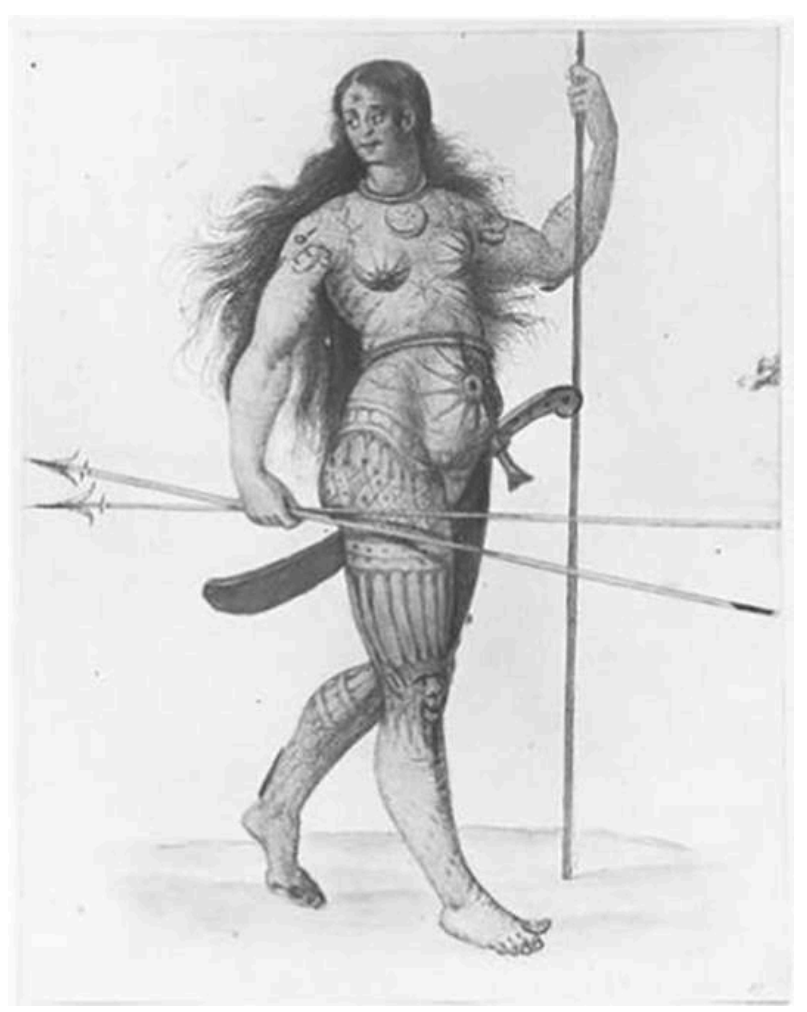

Image in the public domain

The entrance figures in the foreground of Varejão's canvases, as their name conveys, invite the viewer into the painting, welcoming them to the cannibal feast; these figures, as the composition would have it, lure viewers to the corruption of their souls. Nevertheless, by evoking the Picts, ancestors of civilized Europeans through their body art, classical imagery in the physiognomy of the figures, Portuguese entrance figures in the allusion to azulejos, and savagery recalled by European chronicles by the heads they carry, Varejão conflates contradictory references exhibiting the discontinuities within master narratives. She uses the female body as surface in which to layer these references in the Entrance Figure series and showcases the highly constructed nature of representation.

While in Entrance Figure I, the main woman has flower patterns resembling tile ornamentation tattooed on her skin, in Entrance Figure II and III these markings are more similar to the tattoos that gave the Picts their names. ${ }^{17}$ Interestingly, in the Tupinambá culture, these drawings in the male body were, as Staden's testimony recalls, reminders of the individual's participation in rituals of antropofagia, marks of the very incorporation of the Other. The transposition of these markings from the male Picts in De Bry to the female body in Varejão's work further points to how, from the travelers chronicles to De Bry's images, barbarism was transposed from the man to the women while the bodies were cleansed of racial markers through the use of ancient images as types. Varejão's composition highlights these erasures and modifications making them visible. 


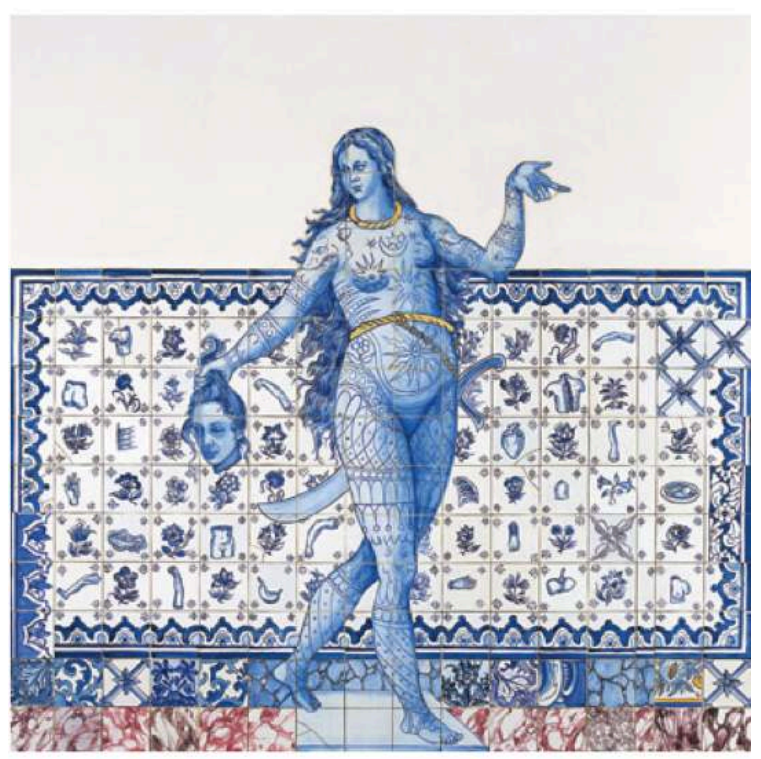

Image in the public domain

In Entrance Figure II and III, (figs. 21 and 22) the body as support is used even more emphatically. The savage/civilized dichotomy that in the earlier work of the series was displayed in the backdrop is here rearranged in the grid of tiles. The ornamental patterns that were tattooed onto the female body in Entrance Figure I are now transferred to the tiled background, while the iconography is subverted. The body in parts becomes the key iconographical marker in the tiled background. Varejão reassociates the body in parts with the practice of eating by referring to the panels depicting cuts of meat found in Portuguese kitchens. Again in the backdrop of Varejão's Entrance Figure II and III, symbols of domesticity such as the tiled panels are juxtaposed with the ultimate symbols of barbarism: the body in parts. 


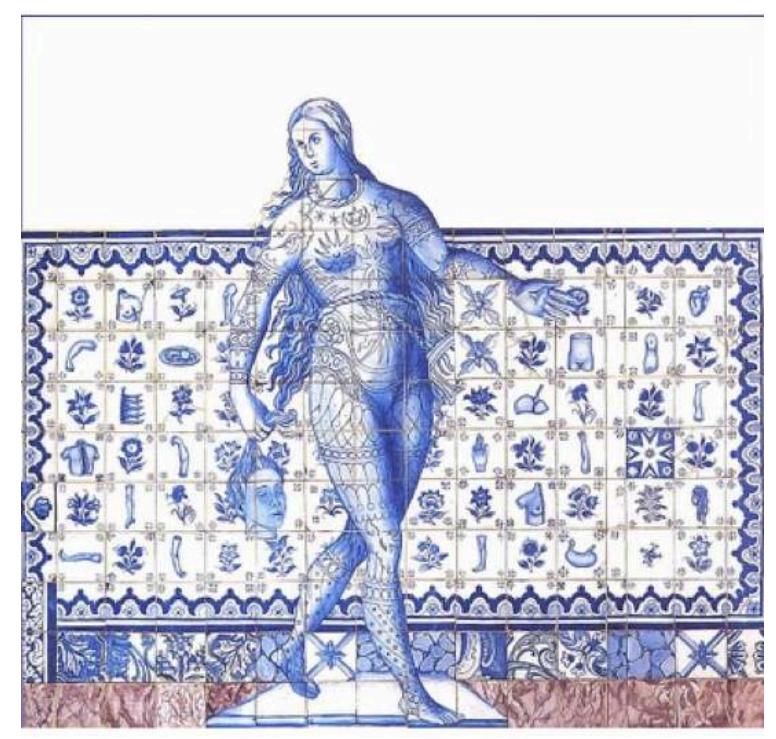

The changes from the first to the last paintings of the Entrance Figure series also demonstrate how Varejão consciously inhabits historical syntax in order to be able to expand and subvert meaning and broader cultural implication from within (NERI, 2001: 16-7). The way she mimics materially the process of consolidation of identity reveals this. While in the first painting there is clearly separated layers of meaning and of references, in the other paintings references are evoked by iconographical markers, diluted in traditional tile ornamentation.

Nevertheless, in Entrance Figure II the background panel and the figure on the front still appear as separate layers because of the difference in the tonal treatment of the main figure. Only in Entrance Figure III does the surface become consistently homogenized. The blues and whites of the forefront figure blend in with the background, the grid runs more comprehensively throughout her body, at times blending with it, as in her right foot, and at others overtaking it, as in the middle tile at her left arm (see details figs. 23 and 24). 
Figures 23 and 24 - Details Entrance Figure III - left foot and right arm

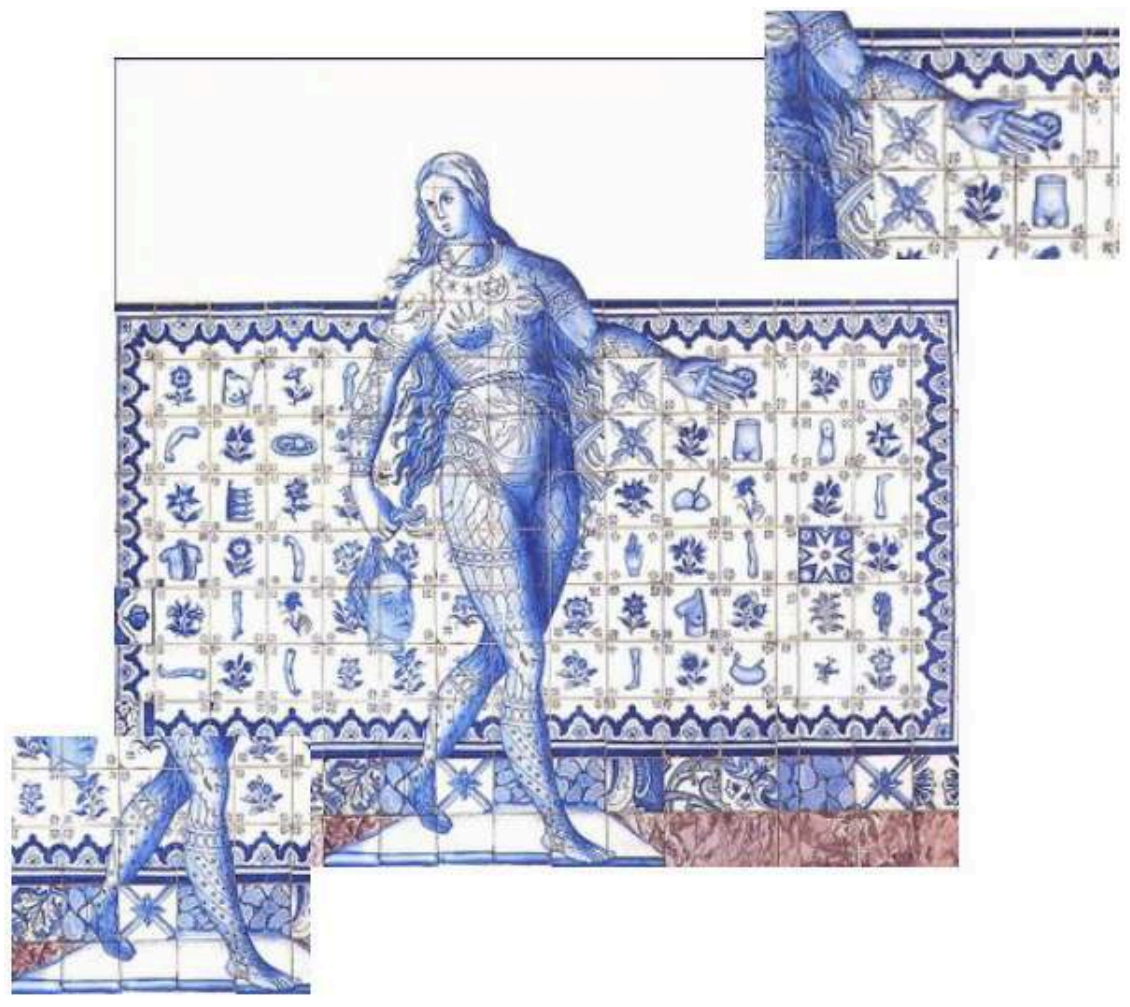

37 The three paintings from the Entrance Figure series are part of an internal narrative; they perform the construction of History and the consolidation of a shared identity. Thus, it is in the construction of representation, and in making this representation homogeneous that Varejão unearths the process of identity making, revealing its highly constructed character and questioning the building blocks of the notion of Brazilianess. Therefore, her art punctures history and reveals the seams produced by the process of cutting and patching past and present together. Varejão shows the violence inherent to the consolidation of the nation by calling attention to its exclusions and bias. By materializing in the series of Entrance Figures the process of collaging and homogenizing disparate sources and stories, art and history became performative in Bevernage's understanding of the term. It is in this way that Varejão's painting endlessly produces folds, wrinkling the smooth surface of Brazilian History.

\section{BIBLIOGRAPHY}

ALBERTI, Leo Battista. Da Pintura. Ed. Da Unicamp, Campinas, 1978.

ANDERSON, Benedict Anderson. Imagined Communities: Reflections on the Origin and Spread of Nationalism. Verso, New York, 2006. 
BARKER, Francis, Peter Hulme, and Margaret Iversen. Cannibalism And The Colonial World. Cambridge, Cambridge University Press 1998.

BENZAQUEM DE ARAÚJO, Ricardo. Guerra e paz: Casa grande e senzala e a obra de Gilberto Freyre nos anos 30. Rio de Janeiro, Editora 34, 1994.

BEVERNAGE, Berber. "Introduction," in: History, Memory, and State-Sponsored Violence: Time and Justice. Routledge, New York, 2012.

BOAVENTURA, Maria Eugenia. "Modernismo e Surrealismo," in: Jackson, K. David.

Transformations of Literary Language in Latin American Literature. Abaporu Press, Austin, 1987.

BOAVENTURA, Maria Eugenia. "Uma edição especial de Oswald de Andrade," in: Primeiro encontro de crítica textual. 0 manuscrito modern e as edições. USP, São Paulo, 1986: 27-40.

BOAVENTURA, Maria Eugenia. A Vanguarda antropofágica. São Paulo, Ática, 1985.

BOAVENTURA, Maria Eugenia. Do órfico e mais cogitações. Prefácio. In: Oswald de Andrade: Estética e Política. São Paulo, Globo, 1976: 7-15.

BOAVENTURA, Maria Eugenia. o Salão e a Selva: uma biografia ilustrada de Oswald de Andrade. Campinas: Editora da UNICAMP; São Paulo, Ex Libris, 1995,

BOAVENTURA, Maria Eugenia. Oswald de Andrade: entre a política e a arte. In: Folhetim.

Suplemento da Folha de S. Paulo, São Paulo, 3 de novembro de 1984: 3- 5.

BOAVENTURA, Maria Eugenia. Oswald e as alegorias da modernidade. Uniletras, Ponta Grossa, 1986.

BOAVENTURA, Maria Eugenia. Um Dicionarista Antropófago. In: ANDRADE, Oswald. Dicionário de Bolso. 2.ed. Organização, introdução e notas: Maria Eugenia Boaventura. São Paulo, Globo, 2007, (Obras completas de Oswald de Andrade): 7-32.

BOPP, Raul. A antropofagia; um programa genuinamente nacionalista. Correio do Povo, Porto Alegre, 12 fev. 1982.

BUARQUE DE HOLLANDA , Sérgio. Raízes do Brasil. Gráfica Manoel Barbosa e Filhos Ltd., Rio de Janeiro, 1936.

CAMAYD-FREIXAS, Erik and José Eduardo González (ed.). Primitivism and identity in Latin America: essays on art, literature, and culture. Tucson, University of Arizona Press, 2000.

CASTEDO, Leopoldo. The Baroque Prevalence in Brazilian Art. Charles Frank Publications, New York, 1964.

CHANADY, Amaryll. "Introduction: Latin American Imagined Communities and the Postmodern Challenge," in: Latin American Identity: a Construction of Difference. University of Minnesota Press, Minneapolis, 1994: IX-XIVI.

CHICANGANA-BAYONA, Yobenj A. "Do Apolo de Belvedere ao Guerreiro Tupinambá: Etnografia e convenções renascentistas," História, vol. 25, No. 2, 2006: 15- 47.

CHICANGANA-BAYONA, Yobenj A. "El festín antropofágico de los indios tupinambá en los grabados de Theodoro De Bry, 1592.” Fonteras de la Historia 10, 2005: 19-72.

CHICANGANA-BAYONA, Yobenj A. and Susana Sawckuz. "Bruxas e índias filhas de Saturno: arte, bruxaria e canibalismo" Revista Estudos Fem., Florianópolis, 2009.

CHICANGANA-BAYONA, Yobenj A. Imago Gentilis Brasilis. Modelos de representação pictórica do índio da Renascença. 2 v. Tese de Doutorado. Universidade Federal Fluminense, Rio de Janeiro, 2004. 
DAMATTA, Roberto and David Hess. The Brazilian Puzzle. Culture on the Borderlands of the Western World. Columbia University Press, New York, 1995.

DAMATTA, Roberto. Carnival, Rogues and Heroes. An Interpretation of the Brazilian Dilemma. Note Dame University Press, Indiana, 2007.

DE ANDRADE, Oswald e Maria Eugênia Boaventura. Os dentes do dragão: entrevistas. Rio de Janeiro, Eidtora Globo, 1990.

DE ANDRADE, Oswald. “Manifesto Antropofágico," In: Revista de Antropofagia, 1928-1929. Facsimile. Editora Abril, São Paulo, 1974.

DE ANDRADE, Oswald. Do Pau-Brasil à Antropofagia e às Utopias. Civilização Brasileira, Rio de Janeiro, 1978.

DE ANDRADE, Oswald. Estética e Política. Pesquisa, Organização, Introdução, Notas e Estabelecimento do texto de Maria Eugênia Boaventura. O Globo, São Paulo, 1992.

DE BRY, Theodore. Admiranda Narratio, Fida Tamen, de Commodis et Incolarum Ritibus Virginiae by Thoma Hariot. Typis Ioannis Wecheli, Sumptibus, Frankfurt, 1590.

DE BRY. Theodor. Americae pars I-XIII. Francoforti ad Moenvm, 1590-1634.

DELEUZE, Gilles. The Fold: Leibniz and the Baroque. University of Minnesota Press, Minneapolis, 1992.

DUSSEL, Enrique. 1492: o encobrimento do outro. A origem do mito da modernidade. Vozes, Petrópolis, 1993.

FERNÁNDEZ RETAMAR, Roberto. Caliban and Other Essays. Minnesota University Press, Minneapolis, 2005.

FREYRE, Gilberto. Order and Progress: Brazil from Monarch to Republic. University of California Press, Berkeley, 1986.

FREYRE, Gilberto. The Master and the Slaves: A Study in the Development of Brazilian Civilization. University of California Press, Berkeley, 1986.

FRY, Peter et al. (Org.). Divisões perigosas: políticas raciais no Brasil contemporâneo. Rio de Janeiro, Civilização Brasileira, 2007.

GALEANO, Eduardo. Open Veins of Latin America: Five Centuries of the Pillage of a Continent, Monthly Review Press, New York, 1973.

GAUDIO, Michael. Engraving The Savage: The New World And Techniques Of Civilization. Minneapolis, University Of Minnesota Press, 2008.

GRACÍA CANCLINI, Nestor. Hybrid Cultures: Strategies for Entering and Leaving Modernity. Minnesota University Press, Minneapolis, 2005.

HILLS, Helen (ed.). Rethinking The Baroque. London, Ashgate, 2011.

KARWATSKY, Paul. “Brazilian Baroque.” Modern Painters 17, London, 2004: 42-4.

KRAMER, Heinrich And James Sprenger. Malleus Maleficarum. O Martelo Das Feiticeiras. Rio De Janeiro, Rosa Dos Tempos, 1993.

LASH, Miranda Isabel. “An Immodest Proposal: Contemporary Cannibalism in Adriana Varejão's Tileworks," MA Thesis, Art History Department, Williams College, 2006.

LESTRINGANT, Frank. O Canibal: Grandeza E Decadencia. Brasilia, Ed. Da Unb, 1997. 
MOFFITT, John F., and Santiago Sebastián. O Brave New People: The European Invention of the American Indian. University of New Mexico Press, Albuquerque, 1996.

MONTAIGNE, Michel de. "Of Cannibals." (1580) in: The Essays of Montaigne, Complete, Project Gutenberg, ebook, 2006.

MORANA, Mabel and Carlos Jaurequi. Revisiting the Colonial Question in Latin America. Iberoamericana , Vervuert, 2008.

MUNANGA, Kabengele. Rediscutindo a mestiçagem no Brasil: identidade nacional versus identidade negra. Belo Horizonte, Autêntica, 2004.

NERI, Louise. “Brave New World: Adriana Varejão's Baroque Territories,” in: Adriana Varejão edited by Paulo Herkenhoff and Louise Neri O Autor, São Paulo, 2001.

ORTIZ, Renato. Cultura brasileira e identidade nacional. São Paulo, Brasiliense, 1994.

PACHECO, Francisco. El Arte de la Pintura. Cátedra, Madrid, 1990.

PAGDEN, Anthony. European Encounters with the New World: From Renaissance to Romanticism. Yale University Press, New Haven, 1993.

PRADO JR, Caio. Formação Do Brasil Contemporaneo. São Paulo, Brasiliense, 1977.

QUINTAS, Georgia. “Antropofagia: As Várias Dimensões Antropológicas. Revista de História e Estudos Culturais Vol. 5, Ano 2, n. 2, 2008.

RIBEIRO, Darcy. The Brazilian People: the Formation and Meaning of Brazil. University of Florida, Gainsville, 2000.

ROCHA DA COSTA, Ricardo Cesar. "O pensamento social brasileiro e a questão racial: da ideologia do "branqueamento" às “divisões perigosas." Revista África e Africanidades, Ano 3, n. 10, agosto, 2010.

SCHWARCZ, Lilian Moritz. "Uma história de "Diferenças e Desigualdades": as doutrinas raciais do século XIX.” In. O espetáculo das raças: cientistas, instituições e questão racial no Brasil 1871-1930. São Paulo, Companhia das Letras, 1993.

SCHWARZ, Roberto. Misplaced Ideas: Essays on Brazilian Culture. Verso, New York, 1992.

SKIDMORE, Thomas. Black into White: Race and Nationality in Brazilian Thought. Duke University Press, Durham, 1993.

SOUZA, Laura De Mello. Inferno Atlantico: Demonilogia E Colonização: Seculos Xvi-Xviii. São Paulo, Companhia Das Letras, 1993.

TODOROV, Tzvetan. The Conquest of America: The question of the Other. New York, Harper \& Row Publishers, 1982.

TOMPKINS, Cynthia Margarita. Latin American postmodernisms: women writers and experimentation. Gainesville, University Press of Florida, 2006.

VAN GROESEN, Michiel. The Representations of the Overseas World in the De Bry Collection of Voyages (1590-1634). Brill, Leiden and Boston, 2008.

WHITEHEAD. Neil L. "Hans Staden and the Cultural Politics of Cannibalism." Hispanic American Historical Review, Duke University Press, 2002: 722-751.

WOOD, James and John Charles Chasteen (ed.). Problems In Modern Latin American History: Sources And Interpretations. New York, Rowman \& Littlefield Publishers, 2009. 
ZAMORA, Lois Parkinson And Monika Kaup (Ed.) Baroque New Worlds: Representation, Transculturation, Counter Conquest. Duke University Press, 2010.

ZIKA, Charles. Body Parts, Saturn And Cannibalism: Visual Representations Of Witches. Assemblies In The Sixteenth Century. Conference: "Le Sabbat Des Sorciers Em Europe," Ecole Normale Superieure De Fontenay-Saint Cloud. 4-7 Nov. 1992.

ZORDAN, Paola Basso Menna Barreto Gomes. “Witches: Figures Of Power." Revista Estudos Fem., Vol.13, N.2, 2005: 331-341.

\section{NOTES}

1. Antropofagia in this article is thought of in the terms of the concept defined by Oswald de Andrade in his 1928 "Manifesto Antropofágo" influenced by the painting Abaporu of Tarsila do Amaral also of 1928. Oswald de Andrade, "Manifesto Antropofágico," In : Revista de Antropofagia, 1928-1929. Facsimile. Editora Abril, São Paulo, 1974.

2. See Chanady, 1994 for more.

3. See the bibliography at the end of this article for the classical references on the subject and the most important works by each of these writers. These intellectuals are from diverse disciplines including literature, anthropology, sociology, literary criticism, and history ; nevertheless this is but a sample of the many disciplines in which the notion of Brazilianess has been a central concern.

4. For more on De Bry's Grand et Petit Voyages, see Anthony Pagden, and Michiel Van Groesen publications in the bibliography.

5. As Louise Neri points out in her discussion of Varejão, the artist has talked about her interest in philosopher Severo Sarduy and how he proposes to abandon the boring, diachronic sequence of master narratives and write without limits, returning to the original meaning of the word text: textile or tissue, considering everything written and everything yet to be written as a single, unique, simultaneous text in which the discourse we initiate at birth is inserted (NERI, 2001: 20). I am interested here in how Varejão's paintings sculpt this malleable tissue, invert and rearrange it.

6. See the references by Erik Camayd-Freixas and José Eduardo González, Mabel Morana and Carlos Jaurequi, John F. MOFFITT and Santiago Sebastián, and James Wood and John Charles Chasteen in the bibliography.

7. See references in the bibliography particularly works of Oswald de Andrade, Maria Eugenia Boaventura, Vera Maria Chalmers and Raul Bopp.

8. Several intellectuals and artists have been influenced directly by Oswald de Andrade's ideas. Particularly impactful has been the 1998 São Paulo Biennial, when Paulo Herkenhoff recuperated these ideas and resignified it, making it the central conceptual axis of the event. See also Elisa Veini's article "Cannibals, Crabs, and Carmen Miranda: How Brazilian Modernists Keep on Unsettling Modernity," Third Text, Vol. 18, Issue, 3, 2004, 229-238; and Lisette Lagnado's "On how the 24th São Paulo Biennial took on cannibalism," Third Text, Vol. 13, Issue 46, 1999, 83-88, as well as the catalogue for the 24th São Paulo Biennial for more references on this reappropriation and its importance for Brazilian contemporary art.

9. See Yobenj A Chicangana-Bayona, Georgia Quintas, Francis Barker, Peter Hulme and Margaret Iversen, and Michael Gaudío in the bibliography.

10. See Chicangana-Bayona's text as well as Paola Zordan, Heinrich Kramer and James Sprenger, Frank Lestringant, Laura de Mello Souza, and Charles Zika.

11. As the Chicangana-Bayona notes in this article, the ideas of Leon Batista Alberti were influential for artists like De Bry in considering the "perturbances" of the soul as proportional to the manner the body should be depicted: Let the movements of the young be light, agreeable, with a 
manifestation of the grandeur of their soul and their strength. The movements of the men must be endowed with a firm and beautiful posture. The movement and posture of the old must reveal their tiredness that they sustain not only with their feet, but also with their hands. Each one thus, must with dignity express with the movements of the body the ones of the soul and the perturbances of their soul should be proportional to the movements of the members... (Chicangana-Bayona, $2006: 21$ ).

12. John 6:57.

13. This has a large literature and since I don't have the possibility of bringing this historiographical discussion to the article, I suggest looking at the bibliography particularly the works of Tzvetan Todorov, Michael Gaudio, Mabel Morana and Carlos Jaurequi, and James Wood and John Charles Chasteen. On the question of the Baroque influence of Brazilian art and architecture see Leopold Castedo, Helen Hills, and Lois Parkinson Zamora and Monika Kaup in the bibliography.

14. See Miranda Lash's work in the bibliography.

15. This article does not delve further into these racial issues (which would be the theme of a whole other article on these works by Varejão and the imagery of de Bry). For more on race as a space of contention in the formation of Brazilian identity see Kabengele Munanga, Lilian Moritz Schwarcz, Peter Fry et al., Ricardo Cesar Rocha da Costa, and Renato Ortiz in the bibliography.

16. John White was a British explorer that created paintings, drawings and sketches that depicted the natives he encountered during his expeditions.

17. For an interesting discussion of the tattoed body of the Picts in John White's work and the interpretation of de Bry of these watercolors in relation to writing and the civilizing mission see Gaudio in the bibliography.

\section{ABSTRACTS}

In the Entrance Figure series, one of the first major works of Brazilian contemporary artist Adriana Varejão, the female body is the canvas in which the artist challenges the historical and artistic canon. It is where the oscillation between the noble savage - in the form of the maternal and domestic muse - and the cannibal - symbolized by the perverse, macabre flesh-eating native - converge and conflate. This article examines how Varejão questions of purity in the construction of a shared identity by using multiple iconographical references in her Entrance Figures. By highlighting the layered nature of the notion of Brazilianess, what Varejão proposes is that the construction of a modern national identity is a process that brings together disparate pasts and visions of the future.

En la serie "Entrance Figures", uno de los primeros grandes proyectos de la artista contemporánea brasileña Adriana Verejão, el cuerpo femenino es el soporte sobre el cual la artista pone a prueba el canon histórico y artístico. Es donde la fluctuación entre el noble salvaje -en la forma de la musa maternal doméstica-y el caníbal-simbolizado por el nativo perverso y carnívoro-convergen y se fusionan. Este artículo analiza la manera en la cual Verejão cuestiona la pureza en la construcción de una identidad compartida utilizando referencias iconográficas en sus "Entrance Figures". Al subrayar la naturaleza estratigráfica del concepto de brasilidad, lo que propone Verejão es que la construcción de una identidad nacional moderna es de hecho un proceso que reúne tanto partes dispares del pasado, como visiones diversas del futuro. 
INDEX

Keywords: Adriana Varejão, antropofagia, civilization and barbarism, Brazilian studies, painting, appropriation, Brazilianess (brasilidade)

Palabras claves: Adriana Varejão, antropofagia, civilización y barbarie, estudios brasileños, pintura, apropiación, brasilianidad (brasilidade)

\section{AUTHOR}

\section{ALICE HEEREN}

$\mathrm{PhD}$ student, Art History, Southern Methodist University - Alice Heeren is a PhD candidate at Southern Methodist University in Dallas, Texas in the Rhetorics of Art, Space and Culture program (RASC/a). Her work explores the creation of national identity in Brazil and its legacy in the contemporary moment particularly in regards to spatial critical practices.

aheerensabat[at]smu.edu

alice.heeren[at]gmail.com 